\title{
Heat supply planning for the ecological housing community Munksøgård
}

\author{
Karlsson, Kenneth Bernard; Petrovic, Stefan; Næraa, Rikke
}

Published in:

Energy

Link to article, DOI:

10.1016/j.energy.2016.08.064

Publication date:

2016

Document Version

Early version, also known as pre-print

Link back to DTU Orbit

Citation (APA):

Karlsson, K. B., Petrovic, S., \& Næraa, R. (2016). Heat supply planning for the ecological housing community Munksøgård. Energy, 115(3), 1733-1747. https://doi.org/10.1016/j.energy.2016.08.064

\section{General rights}

Copyright and moral rights for the publications made accessible in the public portal are retained by the authors and/or other copyright owners and it is a condition of accessing publications that users recognise and abide by the legal requirements associated with these rights.

- Users may download and print one copy of any publication from the public portal for the purpose of private study or research.

- You may not further distribute the material or use it for any profit-making activity or commercial gain

- You may freely distribute the URL identifying the publication in the public portal

If you believe that this document breaches copyright please contact us providing details, and we will remove access to the work immediately and investigate your claim. 


\title{
Heat supply planning for the ecological housing community Munksøgård
}

\author{
Kenneth B. Karlsson, Stefan N. Petrović* \\ Department of Management Engineering, Technical University of Denmark, \\ Produktionstorvet Building 426, 2800 Kongens Lyngby, Denmark \\ Rikke Næraa \\ Danish Energy Agency, Amaliegade 44, 1256 Copenhagen K, Denmark
}

\begin{abstract}
Munksøgård is a housing community near the city of Roskilde, Denmark. In 2014, Munksøgård's residents have agreed to change the existing heat supply system. The choice of future heat supply was narrowed to heat pumps, new biomass boilers and connection to nearby district heating network. The choice was additionally narrowed as a result of the voting at the general assembly.

The present paper presents results from techno-economic energy system analysis, simple private-economic analysis and assessment of externalities related to the heat supply, compares them with the voting results and discusses the differences. The potential inconsistencies between economically rational solutions and choices of end-users are highlighted.

The techno-economic energy system analysis is performed by TIMES-DK ${ }^{1}$ model, which optimizes over all sectors in Denmark until 2050. The connection to district heating proved to be optimal from the system perspective. A spreadsheet model has been developed to perform the private-economic analysis and the evaluation of externalities. New biomass boilers proved to be the cheapest from the private-economic perspective; district heating came close. At the voting, heat pumps and biomass boilers received the most votes. One of these two solutions will be implemented. Why district heating received the least votes calls for detailed investigation.
\end{abstract}

\section{KEYWORDS}

Local heating system; Private-economic analysis; Danish energy system; TIMES-DK model; Voting; Renewable energy supply

\footnotetext{
* Corresponding author. Tel.: +45 24655732.

E-mail addresses: keka@dtu.dk (K.B. Karlsson), stpet@dtu.dk (S.N. Petrović), rin@ens.dk (R.Næraa)

${ }^{1}$ List of abbreviations: The Integrated MARKAL-EFOM System (TIMES); Denmark (DK); Geographic Information Systems (GIS); Centre for Energy, Environment and Health (CEEH); Energy Technology Systems Analysis Programme (ETSAP); Denmark East (DKE); Denmark West (DKW); Design Reference Year (DRY); District Heating (DH); Combined Heat and Power (CHP); Heat Only (HO); Danish Kroner (DKK); Residual sum of squares (RSS); Mean squared error (MSE); A model for the generation and handling of solid waste in Denmark (FRIDA); High Voltage Direct Current (HVDC); Integrated Economic eneRgy Applied Computational Tool (Interact); (O\&M) Operation and Maintenance; Danish Register of Buildings and Dwellings (BBR); Single-family (SF); Multi-family (MF); Wind Lower bound on Production (WLP); Wind Lower bound on Production - Non-Fossil Energy (WLP-NFE); Danish Rational Economic Agents Model (DREAM)
} 


\section{Introduction}

Danish energy system is heading towards a renewable energy based future in 2050. A few other national targets should be met along the way [1, 2]: renewable energy should account for more than $35 \%$ of final energy consumption in 2020, while approximately $50 \%$ of Danish electricity consumption needs to be produced from wind power in 2020. Furthermore, the intention of the Danish Government is that electricity and heat generation has to be $100 \%$ renewable by 2035, and the power plants should not burn coal from 2030. Despite established and clearly defined national targets, lower administrative units such as regions and municipalities are not obliged to have their own targets for transition to renewable energy. For example, Central Denmark Region has set a goal for renewable energy share to $50 \%$ in 2025 [3]. Zealand Region aims for $18 \%$ of wind power and $27 \%$ of regional biomass in region's energy consumption in 2020 [4]. North Denmark Region decided to annually reduce $\mathrm{CO}_{2}$ emissions by $2 \%$ until 2025 [5]. Different goals can be seen on municipal level as well Sams $\emptyset$ 's net balance over a year is $100 \%$ renewable for 10 years [6], Rinkøbing-Skjern expects to be $100 \%$ self-sufficient with renewable energy in 2020 [7], while the municipalities Copenhagen and AaFrhus are planning to be $\mathrm{CO}_{2}$ neutral in 2025 and 2030, respectively $[8,9]$. Below the municipal level, specific renewable energy targets are not set. On that level, district heating companies are deciding on the type of fuel, while private consumers are the ones making decisions on type of heating supply (district heating, heat pumps, oil boiler, etc.), mean of transportation (bicycle, train, gasoline car, etc.), heat and electricity savings, etc.

Energy system analysis has received a lot of attention at the national level. Different aspects of the Danish energy system were analysed within several studies. The Danish energy system as a whole was analysed for the years 2030 and 2050 in [10]. The specific role of district heating was addressed in [11-13], the role individual heat pumps in [14, 15], profitable heat savings in [16,17], while the optimization of waste treatment was analysed in [18, 19]. At a municipal level, district heating in Copenhagen was analysed in [20], while low-temperature district heating and competition between district heating and heat savings in Frederikshavn was addressed in [21, 22]. A renewable energy scenario for Aalborg municipality was addressed in [23] while the integration of renewables for the same municipality was analysed in $[24,25]$.

When it comes to smaller geographical areas such as groups of buildings or a housing community, energy system analysis is usually not applied. At such geographical scales, results from demonstrations or measurement projects are usually reported or operational aspects of a specific technology are discussed. In accordance with this, Bøhm presented results of measurements of consumption, efficiency and losses in domestic hot water systems in 15 residential and public buildings [26]. Harrestrup and Svendsen [27] have performed measurements of heat consumption before and after the renovation of a multi-storey building in Copenhagen with heritage value and have reported reduction of heat consumption of $47 \%$, which proved to be within expected values. Morelli et al. [28] used a multi-storey building in Copenhagen from 1896 as a case-study for three types of energy retrofit measures and concluded that the reduction of energy consumption by $68 \%$ is achievable, but renewable energy sources are needed to achieve a "nearly-zero" energy building. Mørck et al. [29] have investigated cost-effective, low-energy buildings within the demonstration project Class 1 in housing community Stenloese Syd. They have done measurements of gross energy consumption and discovered that it is $180 \%$ higher than the expected. They have identified several possible explanations for the discrepancy, such as the weather conditions, smaller internal heat gains, higher indoor temperature, etc. The choice of heat supply system or whether to renovate a group of buildings largely depends on private-economy and private preferences. 
There is a consensus among residents of the ecological housing community Munksøgård that the existing heating system needs to be changed. The present paper presents three views on the question "Which heat supply system should be chosen by Munksøgård?". First, national energy system analysis until 2050 is performed with TIMES-DK model. The results from this analysis represent the optimal solution seen from the Danish energy system as a whole; Munksøgård is not explicitly modelled, but results can be extracted from the model representing that type of buildings. Hereafter, analysis of Munksøgård's local energy system is performed with a spreadsheet model. These results include private-economy and externalities such as local pollution, noise or stability of supply (the two latter only as a qualitative evaluation). Thirdly, the new heat supply system will be chosen in the democratic voting process at the general assembly in the community. Finally, the differences between solutions will be presented and the challenge in making socio-economically suitable solutions attractive to private consumers will be discussed.

The present paper offers two sets of contributions:

- Heat supply systems on local/communal scale are usually analysed by consultants, while in scientific publications heat supply systems are usually analysed on a very detailed level (single building or a specific heat supply unit, etc.) or on a more aggregated level (municipal, regional, national). In the present paper, our geographical scale is positioned in between very detailed and aggregated level - we analyse new heating system on a level of a housing community with 100 houses in total.

- New heat supply systems are usually analysed from one point of view - purely technical, private-economic, socio-economic, private preferences at end-user level, etc. In the present paper, we analyse the new heating system from three perspectives and discuss the similarities and differences.

However, Munksøgård is just used as a case to illustrate the challenge between planning from a socio-economic and private-economic point of view and realising these investments at enduser level.

\subsection{The Munksøgård community}

Munksøgård is an eco-village built in year 2000 [30]. It is located on the periphery of Roskilde city, which is $40 \mathrm{~km}$ west of Copenhagen, as presented in Figure 1a. It consists of 5 groups of buildings constructed around an old farmhouse, as presented in Figure 1b. The idea was to create a village-like community with focus on resources, environment and local involvement. To create a mixed community of people, the apartments have different sizes and are a mix of rental, share owned and private owned apartments. One group is reserved for younger people, one for older and three for families. Each of these five groups consists of 20 apartments and the total number of people is around 250 .

The special solutions applied at Munksøgård are local district heating based on wood pellet boilers supplemented with solar heating, local waste water treatment system, separation of urine in the toilets, relatively efficient buildings, use of rain water for washing machines and a big green area for gardens and animals (sheep, cattle, pigs, etc.). The village is placed on the edge of Roskilde city having land-zone area on one side and city-zone on the other side.

The community builds on local involvement. Maintenance of sewage system, heating system, green areas and buildings is carried out by the residents. There is a democratic structure with a steering board with 2 persons from each group elected every year for a one year period. The decision power is placed at the general assembly which is meeting twice a year where all households at Munksøgård have a number of votes based on size of their apartments. Between the general assemblies, the steering board can take decisions within their mandate. Besides this system, discussion/information meetings (common meetings) are organized throughout the year. 
Everyone can participate at these meetings, influence the discussions and make proposals for the steering group or general assembly.

\section{Methodology}

This section will present the local spreadsheet model used to perform private-economic analysis of future heat supply systems (in Section 2.1), TIMES models in general (in Section 2.2) and TIMES-DK model of the whole Danish energy system (in Section 2.3).

\subsection{Local spreadsheet model}

To compare the different solutions for the community a spreadsheet model focussed on the private economy was developed. It analyses yearly energy balance for Munksøgård's heating system and the costs and impacts from the possible solutions. A snapshot of the model is shown in Figure 2. In the model, all three alternative solutions are compared against the existing system. It is possible to make different assumptions about fuel costs, heat savings, solar heating share, etc. Technology data sheets provide the model with efficiencies, costs and emission factors. They are based on Technology Data Energy Plants maintained by the Danish Energy Agency [31].

\subsection{TIMES models}

TIMES was developed and is maintained by the Energy Technology Systems Analysis Programme (ETSAP), an Implementing Agreement of the International Energy Agency, established in 1976 [32]. TIMES is a multi-regional, technology-rich, bottom-up model generator used for long-term analysis and planning of regional, national and multi-national energy systems. Additionally, TIMES falls within a group of techno-economic, partial equilibrium model generators assuming full foresight and perfectly competitive markets. It is usually used for simultaneous analysis of all sectors of the energy system, but can be utilised for analysis of specific sectors.

The processes, commodities and commodity flows are the basic elements TIMES models. These elements and their interrelations are presented in Figure 3 - the processes as boxes, commodities and commodity flows as vertical lines. The processes are transforming one or more commodities into one or more different commodities. The commodities consist of: energy carriers (wind, solar radiation, coal, etc.), energy services (heated residential area, illuminated service area, etc.), materials (aluminium, copper, etc.), monetary flows (DKK, EUR, etc.) and emissions $\left(\mathrm{CO}_{2}\right.$, $\mathrm{NO}_{\mathrm{X}}$, etc.).

\subsection{TIMES-DK MODEL}

TIMES model for Denmark, named TIMES-DK is including all sectors of the energy system. It is developed by the Energy Systems Analysis group, DTU Management Engineering, E4SMA and the IntERACT team from the Danish Energy Agency. All authors of the present paper have been members of the project team. Since the present paper deals with the choice of future heat supply, description of general features of TIMES-DK model is followed by the description of power and heat and residential sector. The description of the remaining sectors (Transportation, Private Service, Public service, Construction activity, Manufacturing, Agriculture and Other sectors) is left out. For detailed description of TIMES-DK model, including theoretical 
foundations and descriptions of remaining sectors, the reader should consult model documentation at www.ens.dk/interact.

TIMES-DK model is national, multi-regional energy system model. Denmark is represented with two regions, East Denmark (DKE) and West Denmark (DKW). Electrical power systems of these regions are connected via 600 MW HVDC power cable, while heating systems are not connected.

The domestically available and imported resources are utilised in TIMES-DK to produce electricity, individual and district heat within the Danish energy system. The domestic potentials of non-internationally traded fuels are defined in the model. The domestic onshore wind, offshore wind and wave potentials are obtained from [33], while domestic PV, solar thermal and geothermal potentials are obtained from [34]. The domestic straw, woodchips, wood waste and slurry potentials are based on [35]. The domestic combustible waste potentials are obtained from FRIDA model [36], while waste import from abroad is not enabled for now in TIMES-DK. The summary of domestic renewable energy potentials is presented in Table 1. The entire combustible waste potential is assumed to be incinerated in all analysed scenarios. The long-term price projections for straw, woodchips, wood waste and slurry are obtained from [37]. For internationally traded fuels, long-term price projections are obtained from [38] and their import is not constrained in the model.

Electricity trade is enabled in TIMES-DK. The electricity interconnections with neighbouring countries are represented by physical capacities and import/export price projections from/to each of the neighbouring countries. The price projections, existing transmission capacities and planned transmission expansions are adopted from [39]. To prevent the development of the Danish energy system based on imported electricity, Denmark is constrained to be a net exporter of electricity in all analysed scenarios.

\subsubsection{Power and heat sector}

Electricity and district heat in TIMES-DK are produced in the power and heat sector. After being produced in the power and heat sector, electricity and district heat are being transmitted and distributed to residential consumers. The state of power and heat sector in Base Year ${ }^{2}$ is defined by installed capacities of plants producing electricity only, electricity and heat and heat only. The highly detailed level of data contained in the Energy Producers Count [40] allowed for grouping of plants according to technical properties, size, fuel and geographical region. The retirement profiles are assumed based on years of commission and technical lifetimes.

Each of the existing plants is represented with efficiencies, fixed and variable O\&M costs and availability factors. The plants available for installation after 2010 are additionally described by investment costs. The technology catalogue published by the Danish Energy Agency [31] is used as the source of techno-economic parameters.

\subsubsection{Residential sector}

The residential sector in TIMES-DK is an aggregate of the Danish residential building stock. These buildings are demanding electricity for lighting and electrical appliances, space heating and domestic hot water. The data about buildings in the Base Year is obtained from the BBR dataset [41]. The Danish DRY (Design Reference Year) is used as a source of weather data [42]. The net heating demand in the Base Year is calculated for 72 building groups (characterized by a common use and construction period) according to the methodology presented in [43] and aggregated according to the following properties:

\footnotetext{
${ }^{2}$ Base year is the starting year in the model for which the model is calibrated with the official energy statistics. In the present paper Base Year is 2010.
} 
- Construction period - buildings built before 1972 and after 1972,

- Building type - Single-family and Multi-family ${ }^{3}$ buildings according to classification used in Danish energy statistics [44],

- Region - DKE and DKW,

- Position relative to existing $\mathrm{DH}^{4}$ areas - Central, Decentral and Individual areas.

After the base year, heat demand in the residential sector is driven by the change in the heated area of buildings and the implementation of heat saving measures. The construction rates are calculated for each building group as a difference between housing demand and existing stock affected by demolition. The projections of housing demands are adopted from the Danish Rational Economic Agents Model (DREAM) [45], showing that housing demand in Denmark grows by $0.3 \%$ per year. The annual demolition rate of $0.25 \%$ of the area in 2010 is adopted from [46]. The resulting development of residential building stock is illustrated in Figure 4. It is assumed that the heating demand of new buildings complies with building regulations [47].

There are two options for heat supply of residential buildings in TIMES-DK: district heating and individual heating. District heating is produced at CHP and HO (Heat Only) plants and transmitted to consumers, while individual heating is produced and consumed "on site". Demand-side management options are not represented in the model.

The division of district heating producers in TIMES-DK on Central and Decentral is adopted from Energy Producers Count [40]. Central and Decentral DH producers are supplying buildings located in Central and Decentral DH areas, respectively. Higher heating demands, installed capacities and transmission and distribution efficiencies are the characteristics of Central compared to Decentral DH areas.

Based on the type of heat supply and position relative to existing DH areas heat supply areas are divided into three groups:

1. DH areas - the majority of buildings within DH areas is supplied by DH, but individual heating solutions may be found. Based on the previous discussion DH areas are subdivided into Central and Decentral.

2. Next-to-DH areas - these areas are sharing the border with DH areas. If they are sharing the border with Central DH areas, they are classified as Central. Otherwise, they are classified as Decentral. These areas are supplied from individual heating sources.

3. Individual areas - these areas are not sharing a border with existing DH areas. They are entirely supplied from individual heating sources.

Central, Decentral and Individual areas in DKE are presented in Figure 5. Connection of individually heated buildings within DH areas to DH as well expansion DH networks to Next-toDH areas is enabled in TIMES-DK. Expansion of DH into Individual areas is not enabled. The GIS methodology used for calculating potentials and costs of district heating expansion is presented in detail in [48] and will be briefly summarized.

The investment costs of connecting buildings to existing DH systems are calculated for DH and Next-to-DH areas using equations (1) and (2), respectively:

$$
\begin{gathered}
\mathrm{C}_{\mathrm{DH}}=\mathrm{C}_{\mathrm{CONN}}= \\
\left(\mathrm{c}_{\mathrm{CONN}, \mathrm{s}}+\mathrm{c}_{\mathrm{HE}, \mathrm{s}}\right) \cdot \mathrm{n}_{\mathrm{s}}+\left(\mathrm{c}_{\mathrm{CONN}, \mathrm{m}}+\mathrm{c}_{\mathrm{HE}, \mathrm{m}}\right) \cdot \mathrm{n}_{\mathrm{m}}+\left(\mathrm{c}_{\mathrm{CONN}, \mathrm{l}}+\mathrm{c}_{\mathrm{HE}, \mathrm{l}}\right) \cdot \mathrm{n}_{\mathrm{l}}
\end{gathered}
$$

\footnotetext{
${ }^{3}$ SF and MF will be denoting Single-family and Multi-family buildings throughout the paper, respectively.

${ }^{4} \mathrm{DH}$ will be denoting district heating throughout the paper.
} 
$\mathrm{C}_{\mathrm{NEXT}-\mathrm{TO}-\mathrm{DH}}=\mathrm{C}_{\mathrm{CONN}}+\mathrm{C}_{\mathrm{DIST}}=$
$=\left(\mathrm{c}_{\mathrm{CONN}, \mathrm{s}}+\mathrm{c}_{\mathrm{HE}, \mathrm{s}}\right) \cdot \mathrm{n}_{\mathrm{s}}+\left(\mathrm{c}_{\mathrm{CONN}, \mathrm{m}}+\mathrm{c}_{\mathrm{HE}, \mathrm{m}}\right) \cdot \mathrm{n}_{\mathrm{m}}+\left(\mathrm{c}_{\mathrm{CONN}, \mathrm{l}}+\mathrm{c}_{\mathrm{HE}, \mathrm{l}}\right) \cdot \mathrm{n}_{\mathrm{l}}+\mathrm{c}_{\mathrm{DIST}} \cdot \mathrm{A}$

where used symbols have the following meaning:

$\mathrm{C}_{\mathrm{DH}}, \mathrm{C}_{\mathrm{NEXT}} \mathrm{TO}-\mathrm{DH}-$ Total investment costs of connecting buildings within $\mathrm{DH}$ and Next-to-DH areas to existing DH systems, respectively.

$\mathrm{C}_{\text {CONN }}, \mathrm{C}_{\mathrm{DIST}}$ - Total investment costs in connection and distribution infrastructure, respectively. $\mathrm{n}_{\mathrm{s}}, \mathrm{n}_{\mathrm{m}}, \mathrm{n}_{\mathrm{l}}$ - Number of Small, Medium and Large buildings, respectively. Buildings with annual demand for space heating and domestic hot water lower than $50 \mathrm{MWh}$ are regarded as Small, between 50 and $350 \mathrm{MWh}$ as Medium and buildings with demand greater than $350 \mathrm{MWh}$ are considered as Large.

$\mathrm{c}_{\mathrm{CONN}, \mathrm{s}}, \mathrm{c}_{\mathrm{CONN}, \mathrm{m}}, \mathrm{c}_{\mathrm{CONN}, \mathrm{l}}-$ Specific investment costs of connecting pipes for Small, Medium and Large buildings, respectively. They are expressed in $10^{3} \frac{\mathrm{DKK}}{\text { building }}$.

$\mathrm{c}_{\mathrm{HE}, \mathrm{s}}, \mathrm{c}_{\mathrm{HE}, \mathrm{m}}, \mathrm{c}_{\mathrm{HE}, \mathrm{l}}-$ Specific investment costs of heat exchangers for Small, Medium and Large buildings, respectively. They are expressed in $10^{3} \frac{\mathrm{DKK}}{\text { building }}$.

A - area of a specific Next-to-DH expressed in $\mathrm{km}^{2}$.

It is assumed that the buildings within DH areas need to pay for the connecting pipes and heat exchangers; the buildings in Next-to-DH areas additionally need to cover the cost of distribution infrastructure. In the calculation of connection costs, an assumption is made that all buildings within Next-to-DH areas are connecting to DH. The costs are annuitized with $4 \%$ discount rate, converted into cost curves and presented in Figure 6 for Central DH and Next-to-DH areas located in DKE. It can be observed from Figure 6 that around $40 \%$ of expansion potential within Central DH areas is available at lower cost than the cheapest potential located within Next-to-DH areas. On the other hand, expansion potential within Central Next-to-DH areas in DKE is around two times higher than the expansion potential within Central DH areas. Before being imported into TIMES-DK, cumulative cost curves for expansion of district heating within DH and to Next-to-DH areas are approximated with one pair and two pairs of representative potentials and costs, as shown in Figure 7. After the approximation, "Step 1" in Next-to-DH areas in DKE is 20 $\%$ more expensive than the potential in Central DH areas in DKE and two times less expensive than the corresponding "Step 2".

The individual heating capacities in the Base year are calculated by combining the technology catalogue published by the Danish Energy Agency [31], BBR dataset [41] and Danish Energy Statistics [44]. The decommissioning rate of $6 \%$ is assumed for individual heating capacities. To be able to meet the heating demand after the base year, TIMES-DK can invest in new individual heating capacities; the technology catalogue [31] is used as the source of techno-economic data.

Residential heating demand can be reduced by heat saving measures. The potentials and costs of heat saving measures are calculated for 72 building types according to methodology presented in $[48,49]$. This methodology is graphically presented in Figure 8 and summarized in the following steps:

1. Residential building stock is aggregated into 9 groups according to similar construction period and 8 groups according to use, which results in 72 building groups. This division is adopted from [50]. 
2. For each building group several renovation levels are assumed for each element of building envelope. For each renovation level heat saving potentials are calculated as the difference between heating demand before and after renovation:

$$
\mathrm{HS}_{\mathrm{g}, \mathrm{e}, \mathrm{l}}=\mathrm{HL}_{\mathrm{g}, \mathrm{e}, \mathrm{old}}-\mathrm{HL}_{\mathrm{g}, \mathrm{e}, \mathrm{l}} \text {, }
$$

where the used symbols have the following meaning:

HS - Heat saving potential expressed in kWh per year.

$\mathrm{HL}-$ Heat loss.

$\mathrm{g}-$ One of 72 building groups.

$\mathrm{e}-$ Elements of building envelope, such as walls, floors, roofs, windows and mechanical ventilation systems with heat recovery.

1 - Specific level of heat saving measures. Three different additional insulation thicknesses are assumed for roofs, floors and walls, four different types of windows and one mechanical ventilation system with heat recovery.

old - This subscript means "Before the renovation".

3. Total investment costs are calculated for each renovation level of each element in each building type. Total investment costs are expressed in DKK. The costs are based on [50-52].

4. Specific investment costs are calculated for each renovation level of each element in each building group by dividing investment costs calculated in step 3 with heat saving potential calculated in step 2. Specific investment costs are expressed in $\frac{\text { DKK }}{\text { kWh per year }}$.

5. For each element and each building group the least expensive heat saving level is chosen as the one with lowest value calculated in step 4 . The specific investment costs are annuitized with $4 \%$ discount rate. The least expensive annuitized specific investment costs are expressed in $\frac{\text { DKK per year }}{\text { kWh per year }}$.

6. The investment costs and the associated heat saving potentials for each element and each building group calculated in step 5 are used to construct cumulative cost curves. After that, these curves are aggregated to 24 groups according to construction period (Before 1972 and After 1972), building type (Single-family and Multi-family), position relative to existing DH areas (Central, Decentral and Individual) and region (DKE and DKW).

7. The curves from step 6 are approximated with three pairs of potentials and average costs and used in TIMES-DK. As an example, cumulative potentials and annuitized costs of heat saving measures for single family buildings built after 1972 located in Central areas of DKE presented in Figure 9. Residual sum of squares (RSS) and mean squared error (MSE) are presented to give an indication about discrepancy between actual and approximate curves.

\subsubsection{Analysed scenarios in TIMES-DK}

Three scenarios of the future Danish energy system are compared in the present analysis utilising TIMES-DK model:

- Base - There are no policy constraints imposed on the model. The model is searching for the optimal investments and operation while respecting only technical constraints.

- WLP (acronym from Wind Lower bound on Production) - In addition to Base scenario, at least $50 \%$ of electricity needs to be produced from wind power starting from 2020. This renewable energy target originates from [1].

- WLP-NFE (acronym from Wind Lower bound on Production - Non-Fossil Energy) - In addition to WLP scenario, production of electricity and heat need to be $100 \%$ renewable 
starting from 2035, while whole energy system needs to be $100 \%$ renewable starting from 2050. This renewable energy target originates from [2].

The analysed scenarios will show how politically agreed renewable energy targets affect the optimal development of the Danish energy system. Base scenario presents the development of the Danish energy system until 2050 driven only by minimization of the total system costs. In the WLP scenario minimization of the total system costs is constrained only by the constraint that at least $50 \%$ of electricity needs to come from wind power starting from 2020. WLP-NFE scenario shows how the gradual change from fossil fuels to renewables affects all sectors of the Danish energy system. To ensure that the model will not base future Danish electricity supply on imported electricity, annual import of electricity is constrained to be equal to or less than annual export in both all scenarios.

\section{Heating system in Munksøgård}

\subsection{The existing heating system}

Munksøgård's heating system consists of a heating central which is connected to the five building groups through local district heating pipes. The heat flow in Munksøgård's heating system is obtained from measurements and is presented in Figure 10. There are three boilers in the heating central; two wood pellet boilers and oil boiler serving as back-up. They are presented in Figure 11. Their respective sizes are $200 \mathrm{~kW}, 60 \mathrm{~kW}$ and $250 \mathrm{~kW}$. Hot water storage tanks connected with solar heating plants are installed locally in each housing group. They cover around half of the hot water consumption. The total heated area is $9300 \mathrm{~m}^{2}$ with an average net heat demand of $50 \frac{\mathrm{kWh}}{\mathrm{m}^{2} \text { year }} ; 63 \frac{\mathrm{kWh}}{\mathrm{m}^{2} \text { year }}$ if including heating of domestic hot water. In an average year the boilers are using around $1000 \mathrm{MWh}$ of wood pellets and $110 \mathrm{MWh}$ of oil.

\subsection{The different solutions}

A local working group was assigned to choose heat supply options to be further investigated. The only requirement which new heat supply options needed to fulfil at this stage was that they are not based on fossil fuels. After a rough screening of possibilities, three options were pointed out, namely improved wood pellet boilers, local decentralized heat pumps and connecting to district heating. The existing system will be used as reference to compare with the new solutions.

Improved wood pellet boilers. New generation of wood pellet boilers and monitoring and control systems can make the system much more efficient and easier to run. This solution will also include flue gas cleaning to reduce local air pollution and it will reuse all existing piping in the ground. Pros and cons of this solution are listed in Table 2.

The improved wood pellet boilers will not affect the landscape or cause inconvenience to the inhabitants during installation.

Local decentralized heat pumps. This solution entails installation of five ground-source heat pumps - one in each housing group. This means that the central heating grid will not be used and can be shut off. To supply the heat pumps with adequate amount of heat, pipes with brine have to be buried in a sufficient area. A rule of thumb is that $50 \mathrm{kWh}$ of heat per $\mathrm{m}^{2}$ of horizontal area can annually be supplied to buildings in Denmark. This solution will result in five independent heating systems. Pros and cons of this solution are listed in Table 3. 
GIS analysis confirmed that there is enough ground area to be able to extract enough heat from the ground and thus cover heating demand.

District heating. Munksøgård is placed near Roskilde district heating grid. Only a short connection pipe is needed to connect Munksøgård's local heating network with the central district heating grid. The district heating network in Roskilde is linked to the grid in the Copenhagen area and thereby supplied by several CHP (Combined Heat and Power) plants and waste incineration plants (and some back-up boilers). Pros and cons of this solution are listed in Table 4.

\subsection{The planned decision process}

Decision making about the future heating system at Munksøgård is a democratic process where many factors influence the choice of the residents. The final decision depends on the voting at the general assembly meeting where each household can vote. The factors influencing the choice can be economical, environmental, practical and emotional. A lack of knowledge will leave it up to people's beliefs about these factors. Therefore, to remove as much uncertainty as possible a process lasting more than a year has been started:

1. An "expert" group was established in spring 2014 to describe the different technical solutions, their costs and impacts. Posters have been produced describing each solution. This group was supported by a professional energy consultant.

2. All residents were invited on a meeting in June 2015 where posters and the solutions were presented. The residents were able to ask questions to the "expert group".

3. The posters were put up in each of the five common houses during the summer of 2015 to encourage people to discuss pros and cons of the different solutions.

4. After summer of 2015 a full day workshop was organized. The workshop ended up with an indication of the preferred solution.

5. Shortly after this workshop the matter was treated on the general assembly meeting and a voting between the solutions was carried out.

6. A detailed feasibility study is then started for the chosen solution.

7. The new heating system will be implemented.

\section{Results}

The results from the private-economic analysis are presented in Section 4.1, while the results of three scenarios analysed in TIMES-DK model and the results of voting at the general assembly are presented in Sections 4.2 and 4.3, respectively.

\subsection{Results from the private-economic analysis}

Two sets of results from the spreadsheet model are presented. First, the total private-economic annual costs for each of the solutions are presented in Figure 12. This is the price which consumers need to pay for space heating and domestic hot water. Second, air pollution is presented in Figure 13 and the socio-economic health costs related to these emissions are presented in Figure 14 for each of the solutions. Air pollution attributed to biomass boilers, heat pumps and district heating originate from the local boilers, power and heating plants delivering electricity and district heat, respectively. 
There are two main types of annual costs: the costs of paying for the investment and the fuel costs. The fuel costs in the private-economic analysis are the costs for the fuel "delivered to the door", i.e. they include transportation costs, taxes, etc. The heat pump solution has large investment costs mainly due to digging down several kilometres of pipes to retrieve heat from the ground. The fuel consumed by the heat pumps is electricity bought from the grid. The solution with wood pellet boilers and the district heating solution are very close in costs when using the optimistic assumption for district heating. The uncertainty with the district heating solution is whether the district heating company will overtake the local main grid at Munksøgård. If so, they will deliver the heat directly to each house. If not, the district heating company will deliver the heat to the main local grid, while Munksøgård will be operating this grid. The latter is more expensive to Munksøgård because the heat loss from the Munksøgård's main grid is then included in their heat consumption.

The air pollution can be translated into socio-economic costs from the health impacts caused by the pollutants. The price per emitted pollutant is based on the Danish research centre CEEH (Centre for Energy, Environment and Health, www.ceeh.dk).

From the private-economic point of view the implementation of new efficient wood pellet boilers are the most profitable. Even if health impacts would be somehow included, this solution is still the cheapest. The health costs cannot directly be added to the private economic costs because they are socio-economic costs, i.e. the costs which society experiences in terms of hospital expenses, lost work days, early deaths, etc. A substantial part of these costs are realised in neighbouring countries as air pollution travels across borders. The citizens see these costs through tax payments. Therefore, health costs are very indirectly related to the private-economic costs of a new heating system. If the optimistic assumptions are used for connection to district heating then the costs of two solutions are very close.

\subsection{Results from TIMES-DK}

According to the classification adopted in TIMES-DK, existing buildings in Munksøgård community belong to the group of SF buildings located within Central areas in DKE. The future heat supply of this building group from the energy system point of view is presented in Figure 15. The production of district heating in Central DH plants located in DKE is presented in Figure 16. The district heat is not only delivered to residential sector, but to all sectors in DKE, including residential, industrial, public and private service, manufacturing and agricultural sector. All results regarding heat supply in this chapter are referring to SF buildings in Central heating areas of DKE.

In the Base scenario the heat supply configuration rapidly changes in the first years of the analysed period. Already in 2020 all buildings are connected to district heating. The low price of district heat in Central areas which is mainly produced in coal CHPs is the main reason for high shares of district heating.

Similar development of heat supply to SF buildings located in Central areas of DKE until 2020 occurs in the WLP scenario. Due to assumed decrease of investment costs of natural gas heat pumps, $8 \%$ of heating demand is switching to natural gas heat pumps in 2025. As a consequence of the assumed increase of natural gas price all the analysed buildings are switching back to district heating after 2040. Due to high electricity production from wind turbines, the wastefuelled CHPs can't get enough operating hours for economical operation and are switching to heat-only production. The significant part of district heat in this scenario is produced from waste boilers, while large-scale heat pumps contribute with 8-15\%.

In the WLP-NFE scenario, all SF buildings located in Central areas of DKE are connected to district heating starting from 2020 . This remains the case all the way until 2050, when it is found 
to be optimal to supply $12 \%$ of the demand by individual heating sources. Due to the renewable energy constraints the use of coal for production of district heating rapidly declines. On the other hand, the utilisation of wind resource and production of district heating from large-scale heat pumps is the highest in the WLP-NFE scenario. Significant share of district heat in Central areas in this scenario comes as waste heat from production of biofuels.

In parallel with switching to district heating, all scenarios are characterized by reduction of heating demand by a combination of heat saving measures, demolition of old and construction of new buildings. As a result of that, heating demand in 2050 in Base scenario is reduced by $36 \%$ compared to 2010, while the reductions in both WLP and WLP-NFE scenarios are 42 $\%$. If this is seen in the light of the assumed increase of heated area by $27 \%$ over the same period, then the specific heating demands per unit of heated area are decreased by $50 \%$ in Base scenario and $56 \%$ in WLP and WLP-NFE scenarios.

The development of heat supply from individual heating sources is presented in Figure 17. The strong decline in amount of heat delivered from 2010 to 2015 is observed in all scenarios. In the Base scenario the individual heating options are completely abandoned after 2015. In the WLP scenario, around $8 \%$ of heating demand of SF buildings located within Central areas of DKE is covered by natural gas heat pumps between 2025 and 2040. The individual heating options are abandoned after 2015 in the WLP-NFE scenario and are reappearing in 2050 in the form of airsource heat pumps and solar heating. The main reasons behind the decline of individual heating options is switching to district heating and combined effect of heat savings, demolition of existing and construction of new buildings.

Results from TIMES-DK represent optimal solution for Danish energy system as whole, i.e. the development of Munksøgård is not explicitly modelled. However, general conclusions regarding future heat supply in Munksøgård can be drawn based on the national-level analysis. The buildings in Munksøgård belong to the group of SF buildings located within Central areas in DKE. They are supplied from biomass and oil boilers in Base Year.

In all scenarios, individual oil boilers stop delivering heat to SF buildings after 2012, while share of individual biomass boilers drop after 2012 before being phased out after 2015. Small share of heating demand in WLP scenario is covered by natural gas heat pumps. However, in case of Munksøgård the natural gas grid is further away than the $\mathrm{DH}$ grid and the connection costs to the natural gas grid have not been included in the investment costs.

In order to discover how sensitive Munksøgård's future heat supply configuration is to the change of general discount rate in TIMES-DK, its value is changed to $2 \%, 6 \%$ and $8 \%$. However, these changes did not make significant changes in results, i.e. district heating proved to be the optimal heat supply option for all or almost all SF buildings located within Central DH areas in DKE. For analysed discount rates, the share of DH after 2020 was 100\% in Base scenario and over $90 \%$ in WLP and WLP-NFE scenarios.

The conclusion, considering local conditions, is therefore that Munksøgård should connect to the DH grid in Roskilde. It can also be concluded that reduction of heat consumption by 5-10\% should be achieved by implementing heat saving measures - this could be reached by replacing all windows with more efficient ones.

\subsection{Voting results}

The general assembly meeting was held in autumn of 2015. The choice of a new heating system is treated at the general assembly meeting and a voting between the solutions was carried out.

After seeing the presentations and posters of different solutions, asking questions to the "expert group" and having several discussions of pros and cons, the residents of Munksøgård housing community voted in the following way:

- Wood pellets boilers received $36 \%$ of votes, 
- Ground-source heat pumps $35 \%$ of votes,

- Connection to district heating received $29 \%$ of votes.

For the two solutions with the highest number of votes, a detailed feasibility study is started. The cheaper out of two solutions will be implemented and is planned to be in operation from start of 2016 heating season.

\section{Discussion}

The socio-economic analysis showed that Munksøgård housing community should connect to nearby district heating grid. This confirms findings of previous studies that from the socioeconomic perspective buildings located within existing district heating areas should be connected to district heating [11-13]. The private-economic analysis showed that new biomass boiler is the cheapest solution; connecting to district heating was a bit more expensive. If the analysed heating system would be used to supply commercial or office buildings the decision process would finish at this point and the cheapest solution from private-economic perspective would be chosen. Since there are only residential buildings in Munksøgård, the private-economic analysis does not entirely represent residents' choices, i.e. the private preferences play important role. However, if the differences in costs between different solutions would be bigger or if heating bills would constitute higher share of households' expenses, the residents would probably be choosing the cheapest solution. To account for different private preferences the decisions are made in the democratic voting process.

On the voting, the heat pumps and biomass boilers ranked higher than he connecting to district heating. The voting results raise the question: "Why the connection to district heating was not chosen by the residents?" The authors of the present paper believe the reason was not that the residents were not well informed. They were informed that district heating is well tested technology and that there can be no fear weather it will work or not. They were also informed that the wood pellet boilers need more local maintenance and produce more air pollution while heat pumps have a risk of not being able to produce enough heat in the coldest days.

However, several possible explanations were provided by the residents:

- The differences in prices are not big enough to be able to dictate the choice of future heat supply.

- People feel safer and in control when their local heat supply system is in their close neighbourhood. In that sense, heat pumps and biomass boilers are seen as local systems, while district heating is not.

- The residents have the impression that district heating is provided by powerful companies which can decide on the price of heat and whether to provide heat or not. This is however not the case in Denmark. District heating companies in Denmark are owned by consumers and are not allowed to make profit, i.e. the consumers are controlling the price. Even though the wood pellets and electricity for heat pumps are also delivered by big companies as well, they do not have the same reputation.

A detailed sociological study is needed to discover the reasons behind the residents' choices. Future work may include this kind of study.

\section{Conclusion}

Due to increasing amount of breakdowns, residents of Munksøgård housing community decided to change the local heating system. The issues on a communal scale are usually 
analysed by energy consultants from a private-economic perspective, while very detailed level (single building or a specific heat supply unit, etc.) or a more aggregated level (municipal, regional, national) is usually reserved for scientific publications. Instead of that, in the present paper geographical scale is positioned in between very detailed and aggregated level while the new heat supply system is analysed from three different perspectives (private-economic, private-economic with included externalities and socio-economic). These two aspects are considered to be main contributions of the present paper. The decisions are, however made in a democratic voting process.

Private-economic considerations were analysed with a spreadsheet model of the local heating system. Different solutions including connection to nearby district heating network, local decentralized heat pumps and new wood pellet boilers have been compared with existing system. New wood pellet boilers are the least expensive solution even when monetised health costs from air pollution are taken into account. The connection to nearby district heating network has very similar costs. The main uncertainty in this analysis is whether the district heating company will measure the heat delivery at each individual consumer or to the housing community as one. The latter is more expensive to Munksøgård. Due to high installation costs, local decentralized heat pumps were uncompetitive with other solutions. The evaluation of noise, workload and other inconveniences cannot be priced easily.

The socio-economic considerations were analysed with TIMES-DK model of the whole Danish energy system. An analysis until 2050 was performed. The buildings in Munksøgård were not explicitly modelled, but represented by a group of single-family buildings, built after 1972 and located in Central areas of East Denmark. In all scenarios, the connection of these buildings to district heating proved to be optimal for the energy system as a whole.

In a democratic voting process wood pellet boilers and decentralized heat pumps received highest amount of votes. The connection to nearby district heating network received only 29 $\%$ of votes.

In case of Munksøgård, the connection to district heating was clearly the best solution from socio-economic perspective and competitive from private-economic and externalities' perspectives. However, it was not chosen by the residents. This provides valuable learnings for decision makers and architects of the future Danish energy system. If socio-economically sound policy targets are put up, then it needs to be ensured that these solutions perform the best private-economically as well; otherwise, it cannot be expected that individuals will follow the optimal road for the society. Certain solutions can be made private-economically attractive by introducing relevant policy measures such as supporting schemes, taxes and regulation. If socio-economically optimal solutions are made private-economically attractive, then it is expected that they will be chosen by individuals. But, if such a solution is not chosen by individuals then a detailed investigation needs to be undertaken in order to understand the social and behavioural factors behind the decisions.

\section{Acknowledgment}

The development of TIMES-DK model utilised in this paper was funded by the Danish Energy Agency. The work presented in this paper is a result of the research activities of the Strategic Research Centre for 4th Generation District Heating (4DH), which has received funding from Innovation Fund Denmark.

\section{References}

1. Danish Ministry of Climate, Energy and Buildings. (2012). The Governments' energy 
and climate political goals and the results of the energy agreement in 2020.

$<$ http://www.kebmin.dk/sites/kebmin.dk/files/klima-energi-bygningspolitik/dansk-klimaenergi-

bygningspolitik/energiaftale/Faktaark\%202\%20energi\%20og\%20klimapolitiske\%20mal.p df> [accessed 15.04.15] [in Danish]

2. The Danish Government. (2011). Our energy. <http://www.ens.dk/DA-DK/politik/danskklima-og-energi-politik/voresenergi/Sider/Forside.aspx >; [accessed 15.04.15] [in Danish].

3. Central Denmark Region. (2012). Perspectives for 50\% renewable energy in Central Denmark Region in $2025 . \quad<$ http://www.rm.dk/siteassets/regionaludvikling/energi/perspektivplan/energiperspektivplan-for-50-procent-ve-i-regionmidtjylland.pdf $>$ [accessed 15.04.15] [in Danish].

4. Zealand Region. (2012). Resource efficiency and renewable energy. $<$ http://www.regionsjaelland.dk/Miljo/klima-og-miljoe/gr\%C3\%B8nkomite/Documents/GKbaggrund-ressourceogVE.pdf> [accessed 15.04.15] [in Danish].

5. Website of North Denmark Region. (2012). Climate in North Denmark Region. http://www.rn.dk/Om-Region-Nordjylland/KlimaRegion.aspx [accessed 15.04.15] [in Danish].

6. Website of Sams $\varnothing$ municipality - Energy and Climate section. http://www.samsoe.dk/site.aspx?MenuID=174\&Langref=1\&Area=\&topID=\&ArticleID=6 945\&expandID=2151 [accessed 15.04.15] [in Danish].

7. Energy 2020. http://www.energi2020.dk/ ; [accessed 15.04.15] [in Danish].

8. Copenhagen municipality. (2012). Climate plan for Copenhagen in 2025 - green, smart and $\mathrm{CO}_{2}$-neutral city. 〈http://kk.sites.itera.dk/apps/kk_pub2/pdf/930_QP7u8mn5bb.pdf> [accessed 15.04.15] [in Danish].

9. Aarhus municipality website $-\mathrm{CO}_{2}$ neutrality. http://www.gogreenwithaarhus.dk/en/Maal/CO2-neutral.aspx [accessed 15.04.15].

10. Lund, H., \& Mathiesen, B. V. (2009). Energy system analysis of $100 \%$ renewable energy systems-The case of Denmark in years 2030 and 2050. ENERGY, 34(5), 524-531. doi:10.1016/j.energy.2008.04.003

11. Münster, M., Morthorst, P. E., Larsen, H. V., Bregnbæk, L., Werling, J., Lindboe, H. H. \& Ravn, H. (2012). The role of district heating in the future Danish energy system. Energy, 48(1), 47-55. doi:10.1016/j.energy.2012.06.011

12. Lund, H., Moller, B., Mathiesen, B. V., \& Dyrelund, A. (2010). The role of district heating in future renewable energy systems. Energy, 35(3), 1381-1390. doi:10.1016/j.energy.2009.11.023

13. Moller, B., Lund, H. (2010). Conversion of individual natural gas to district heating: Geographical studies of supply costs and consequences for the Danish energy system. Applied Energy 87, 1846-1857. doi:10.1016/j.apenergy.2009.12.001

14. Hedegaard, K., Mathiesen, B. V., Lund, H., \& Heiselberg, P. (2012). Wind power integration using individual heat pumps - Analysis of different heat storage options. Energy, 47(1), 284-293. doi:10.1016/j.energy.2012.09.030

15. Hedegaard, K., \& Münster, M. (2013). Influence of individual heat pumps on wind power integration - Energy system investments and operation. Energy Conversion and Management, 75, 673-684. doi:10.1016/j.enconman.2013.08.015

16. Tommerup, H., \& Svendsen, S. (2006). Energy savings in Danish residential building stock. Energy and Buildings, Energy Build, 38(6), 618-626. doi:10.1016/j.enbuild.2005.08.017

17. Zvingilaite, E., \& Balyk, O. (2014). Heat savings in buildings in a $100 \%$ renewable heat and power system in Denmark with different shares of district heating. Energy and Buildings, 82, 173-186. doi:10.1016/j.enbuild.2014.06.046
Field Code Changed

Field Code Changed

Field Code Changed

Field Code Changed

Field Code Changed

Field Code Changed

Field Code Changed

Field Code Changed 
18. Münster, M., \& Meibom, P. (2011). Optimization of use of waste in the future energy system. Energy, 36(3), 1612-1622. doi:10.1016/j.energy.2010.12.070

19. Münster, M., Ravn, H., Hedegaard, K., Juul N., Ljunggren Söderman, M. (2015). Economic and environmental optimization of waste treatment, Waste Management, Available online 13 January 2015, http://dx.doi.org/10.1016/j.wasman.2014.12.005.

20. Harrestrup, M., \& Svendsen, S. (2014). Heat planning for fossil-fuel-free district heating areas with extensive end-use heat savings: A case study of the Copenhagen district heating area in Denmark. Energy Policy, 68, 294.

21. Lund, H., \& Østergaard, P. A. (2011). A renewable energy system in Frederikshavn using low-temperature geothermal energy for district heating. Applied Energy, 88(2), 479-487. doi:10.1016/j.apenergy.2010.03.018

22. Sperling, K., \& Möller, B. (2012). End-use energy savings and district heating expansion in a local renewable energy system. Applied Energy, 92, 831-842. doi:10.1016/j.apenergy.2011.08.040

23. Ostergaard, P. A., Mathiesen, B. V., Moller, B., \& Lund, H. (2010). A renewable energy scenario for Aalborg Municipality based on low-temperature geothermal heat, wind power and biomass. ENERGY, 35(12), 4892-4901. doi:10.1016/j.energy.2010.08.041

24. Ostergaard, P. A. (2013). Wind power integration in Aalborg Municipality using compression heat pumps and geothermal absorption heat pumps. Energy, 49(1), 502-508. doi:10.1016/j.energy.2012.11.030

25. Ostergaard, P. A. (2012). Comparing electricity, heat and biogas storages' impacts on renewable energy integration. Energy, 37(1), 255-262. doi:10.1016/j.energy.2011.11.039

26. Bøhm, B. (2013). Production and distribution of domestic hot water in selected Danish apartment buildings and institutions. Analysis of consumption, energy efficiency and the significance for energy design requirements of buildings. Energy Conversion and Management, 67, 152-159. 10.1016/j.enconman.2012.11.002

27. Harrestrup, M., \& Svendsen, S. (2015). Full-scale test of an old heritage multi-storey building undergoing energy retrofitting with focus on internal insulation and moisture. Building and Environment, 85, 123-133. doi:10.1016/j.buildenv.2014.12.005

28. Morelli, M., Ronby, L., Mikkelsen, S. E., Minzari, M. G., Kildemoes, T., \& Tommerup, H. M. (2012). Energy retrofitting of a typical old Danish multi-family building to a "nearly-zero" energy building based on experiences from a test apartment. Energy and Buildings, 54, 395-406. doi:10.1016/j.enbuild.2012.07.046

29. Mørck, O., Thomsen, K. E., \& Rose, J. (2012). The EU CONCERTO project Class 1 Demonstrating cost-effective low-energy buildings - Recent results with special focus on comparison of calculated and measured energy performance of Danish buildings. Applied Energy, 97, 319-326. doi:10.1016/j.apenergy.2012.01.057

30. Munksøgård housing community (2016). Munksøgård. www.munksoegaard.dk [accessed 01.05.16]

31. Danish Energy Agency (DEA) (2013). Technology Data for Energy Plants - Individual Heating Plants and Energy Transport. http://www.ens.dk/node/2252 [accessed 15.04.15]

32. International Energy Agency (IEA) (2016). Energy Technology Systems Analysis Program (ETSAP). http://www.iea-etsap.org/ [accessed 01.05.16]

33. RIS $\varnothing$ DTU \& Ea Energianalyse (2010). Future scenarios and measures, Sector Analysis Electricity and heat supply. <http://www.ens.dk/sites/ens.dk/files/politik/dansk-klimaenergipolitik/klimakommissionen/groen-energi/baggrundsrapporter/ Sektoranalyse el_og varmeforsyning.pdf > [accessed 15.04.15] [in Danish]

34. Danish Commission on Climate Change Policy (2010). Green energy - the road to a Danish energy system without fossil fuels.<http://www.ens.dk/politik/dansk-klimaenergipolitik/klimakommissionen/gron-energi > [accessed 15.04.15] [in Danish]

Field Code Changed

Field Code Changed

Field Code Changed

Field Code Changed 
35. Danish Energy Agency (DEA) (2014). Energy Scenarios towards 2020, 2035 and 2050. http://www.ens.dk/sites/ens.dk/files/dokumenter/publikationer/downloads/energiscenarier _-_analyse_2014_web.pdf [accessed 15.04.15] [in Danish]

36. Andersen, F. M., \& Larsen, H. V. (2012). FRIDA: A model for the generation and handling of solid waste in Denmark. Resources, Conservation and Recycling, Resour. Conserv. Recycl, 65, 47-56. doi:10.1016/j.resconrec.2012.04.004

37. Ea Energy Analyses (2013) Analysis of biomass prices - Future Danish Prices for Straw, Wood Chips and Wood Pellets. http://www.ens.dk/sites/ens.dk/files/undergrundforsyning/vedvarende-energi/bioenergi/analyse-bioenergidanmark/analysis_of biomass_prices_2013.06.18 - final_report.pdf [accessed 15.04.15]

38. Ea Energy Analyses (2014). Update of fossil fuel and $\mathrm{CO}_{2}$ price projection assumptions Convergence Pathway. http://www.ens.dk/sites/ens.dk/files/info/tal-kort/fremskrivningeranalyser-modeller/samfundsoekonomiske-beregningsforudsaetninger/2014/convergence methodology final.pdf [accessed 15.04.15]

39. Energinet.dk (2014). Energinet.dk's analysis assumptions $2014-2035$. http://energinet.dk/SiteCollectionDocuments/Danske\%20dokumenter/El/Energinet\%20dk s\%20analyseforuds\%C3\%A6tninger\%202014-2035\%20maj\%202014\%20final.pdf [accessed 15.04.15]

40. Danish Energy Agency (DEA) (2013). Energy producers count 2010-2012.

41. Ministry of Housing, Urban and Rural Affairs (2014). BBR dataset

42. P.G. Wang, M. Scharling, K.P. Nielsen, K.B. Wittchen, C. Kern-Hansen (2013). 20012010 Danish Design Reference Year, Danish Meteorological Institute. <http://www.dmi.dk/fileadmin/user_upload/Rapporter/TR/2013/TR13-19.pdf> [accessed 10.07.2015]

43. Petrovic, S., \& Karlsson, K. (2014) Model for Determining Geographical Distribution of Heat Saving Potentials in Danish Building Stock. ISPRS International Journal of GeoInformation, 3(1), 143-165. doi:10.3390/ijgi3010143

44. Danish Energy Agency (2014). Energy statistics 2013. < http://www.ens.dk/info/talkort/statistik-nogletal/arlig-energistatistik $>$ [accessed 15.04.15] [in Danish].

45. Hansen, J. Z., Stephensen, P. \& Kristensen, J. B. (2013). Modeling Household Formation and Housing Demand in Denmark - The Dynamic Microsimulation Model SMILE, $\begin{array}{lll}\text { DREAM } & \text { Report, } & \text { December }\end{array}$ <http://www.dreammodel.dk/pdf/HousingDemand2013.pdf > [accessed 15.04.15]

46. Danish Energy Agency (2014). Strategy for renovation of buildings. http://www.ens.dk/sites/ens.dk/files/byggeri/Strategi-for-energirenovering-afbygninger/strategi-for-energirenovering-af-bygninger-web-050514.pdf [accessed 15.04.15] [in Danish].

47. Danish Energy Agency (2014). Building regulations - Energy consumption. < http://bygningsreglementet.dk/br10_05 id104/0/42> [accessed 15.04.15] [in Danish].

48. Petrovic, S., \& Karlsson, K. B. (2014). Danish heat atlas as a support tool for energy system models. Energy Conversion and Management, 87, 1063-1076.

49. Petrović, S., \& Karlsson, K. (2016). Ringkøbing-Skjern energy atlas for analysis of heat saving potentials in building stock. Energy. doi:10.1016/j.energy.2016.04.046

50. Wittchen KB (2009) Potential energy savings in existing buildings. Hørsholm: Danish Building Research Institute. http://www.sbi.dk/miljo-ogenergi/energibesparelser/potentielle-energibesparelser-i-det-eksisterendebyggeri/potentielle-energibesparelser-i-det-eksisterende-byggeri

51. Wittchen, K. B. (2010). SBi 2010:56 Danske bygningers energibehov i 2050. http://www.sbi.dk/miljo-og-energi/energibesparelser/danske-bygningers-energibehov-i2050/danske-bygningers-energibehov-i-2050
Field Code Changed

Field Code Changed

Field Code Changed

Field Code Changed

Field Code Changed

Field Code Changed

Field Code Changed 
52. Wittchen, K. B., Kragh, J., \& Aggerholm, S. (2014). Potential heat savings with continuous building renovation until 2050. (1 ed.) Copenhagen: Danish Building Research Institute (SBI) [in hanish]. http://www.sbi.dk/miljo-ogenergi/energibesparelser/potentielle-varmebesparelser-ved-lobende-bygningsrenovering$\underline{\text { frem-til-2050 }}$

\section{Tables and figures}

Table 1. Domestic renewable energy potentials

\begin{tabular}{lc}
\hline Type of renewable energy & Potential \\
\hline Geothermal (MW) & 629 \\
Wind onshore (MW) & 8000 \\
Wind offshore (MW) & 50000 \\
Wave (MW) & 3175 \\
Solar PV (MW) & 9000 \\
Solar thermal (MW) & 15432 \\
Straw (PJ) & 40 \\
Wood chips (PJ) & 148 \\
Combustible waste in 2015 (PJ) & 39 \\
Combustible waste in 2050 (PJ) & 49 \\
\hline
\end{tabular}

Table 2. Pros and cons of improved wood pellet boilers

\begin{tabular}{cc}
\hline Pros & Cons \\
\hline $\begin{array}{c}\text { Lowest investment costs compared to other } \\
\text { solutions }\end{array}$ & Professionals are needed for repairs and \\
maintenance \\
$\mathrm{CO}_{2}$ emissions originate originates only from \\
transportation & Risk of breakdowns (mainly due to wood \\
Stable operation & pellet transport system) \\
& $\begin{array}{c}\text { Big trucks with wood pellets arrive once a } \\
\text { week in the cold period }\end{array}$ \\
Improved local air quality & Depends on limited biomass resources \\
Locally known technology & Flue gas system creates noise \\
\hline
\end{tabular}

Table 3. Pros and cons of local decentralized heat pumps

\begin{tabular}{cc}
\hline Pros & Cons \\
\hline No noise & Needs thorough monitoring and regulation \\
$\mathrm{CO}_{2}$ emission originate only from electricity & Will not be able to deliver enough heat in the \\
production & coldest periods (needs electric supplement) \\
Less maintenance compared to the wood & Leakage in underground pipes is difficult to \\
pellet boiler due to fewer mechanical parts & find and repair \\
\hline
\end{tabular}


No local air pollution

A big ground area is needed for the underground pipes

Fits well into the future Danish energy system

Table 4. Pros and cons of connection to Roskilde district heating grid

\begin{tabular}{cc}
\hline Pros & Cons \\
\hline No noise & $\begin{array}{c}\text { Heat price is set by Roskilde Forsyning (the } \\
\text { local distribution company) } \\
\text { Bereakdown on main district heating grid will } \\
\text { influence heat supply at Munksgård }\end{array}$ \\
$\begin{array}{c}\text { Minimum need for monitoring and regulation } \\
\text { Fits well into the future Danish energy system }\end{array}$ \\
\hline
\end{tabular}

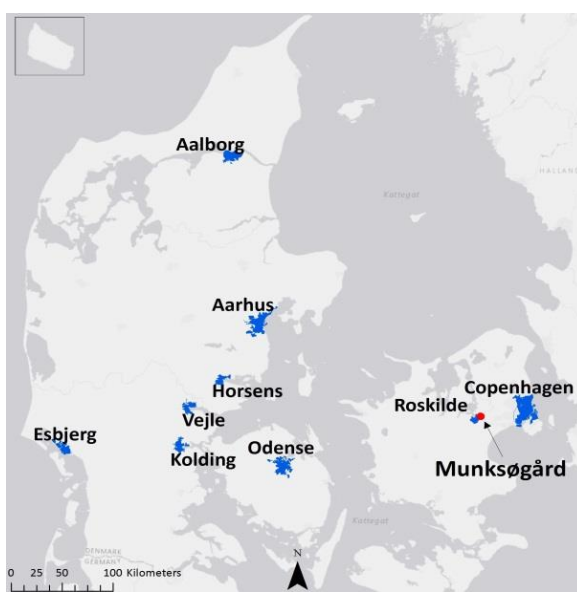

Figure 1a. Location of Munksøgård

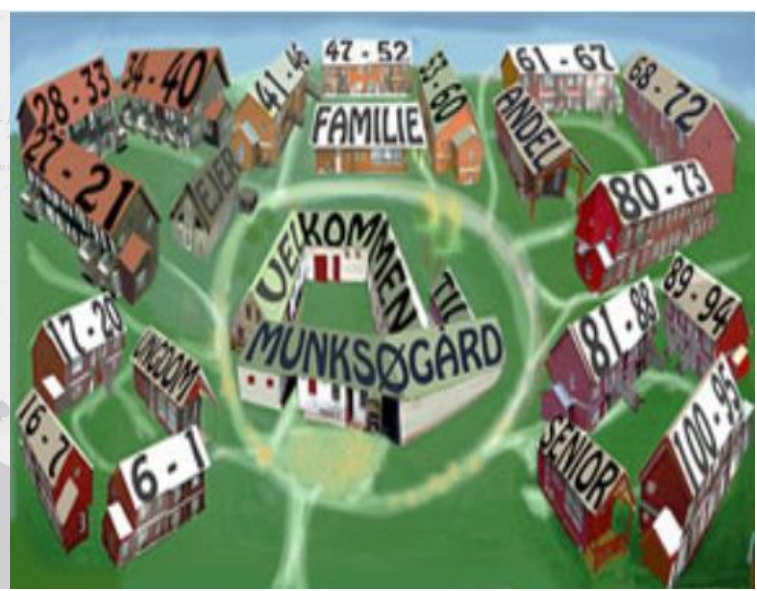

Figure 1b. Five groups of buildings around an old farmhouse 


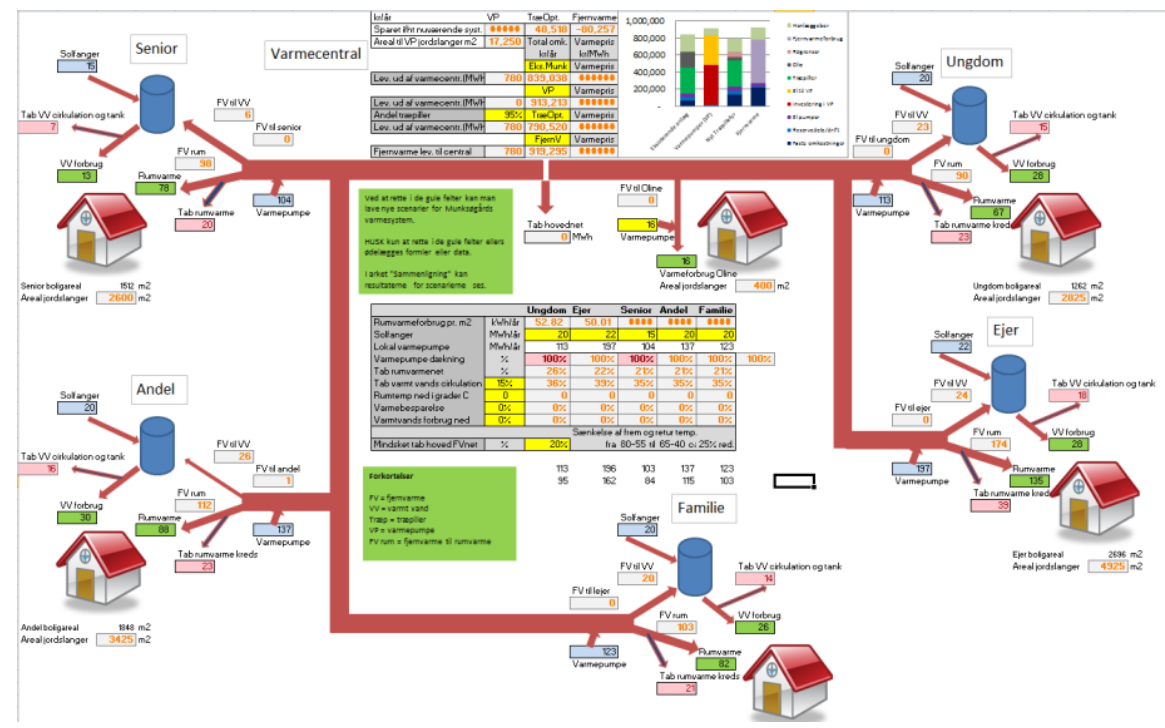

Figure 2. Munksøgård Heating System Model.

District heat Heat from pipeline Residential heat

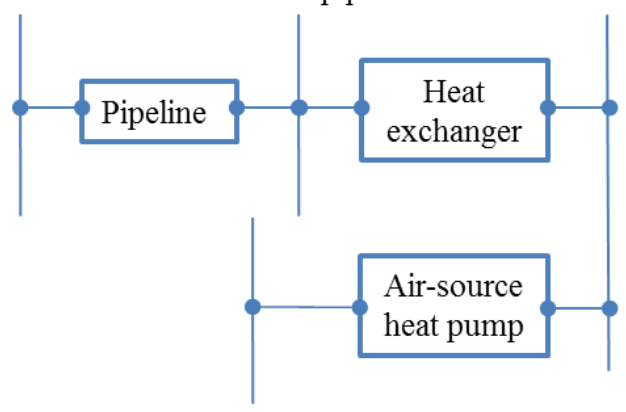

Residential electricity

Figure 3. Basic elements of TIMES models: processes, commodities and commodity flows

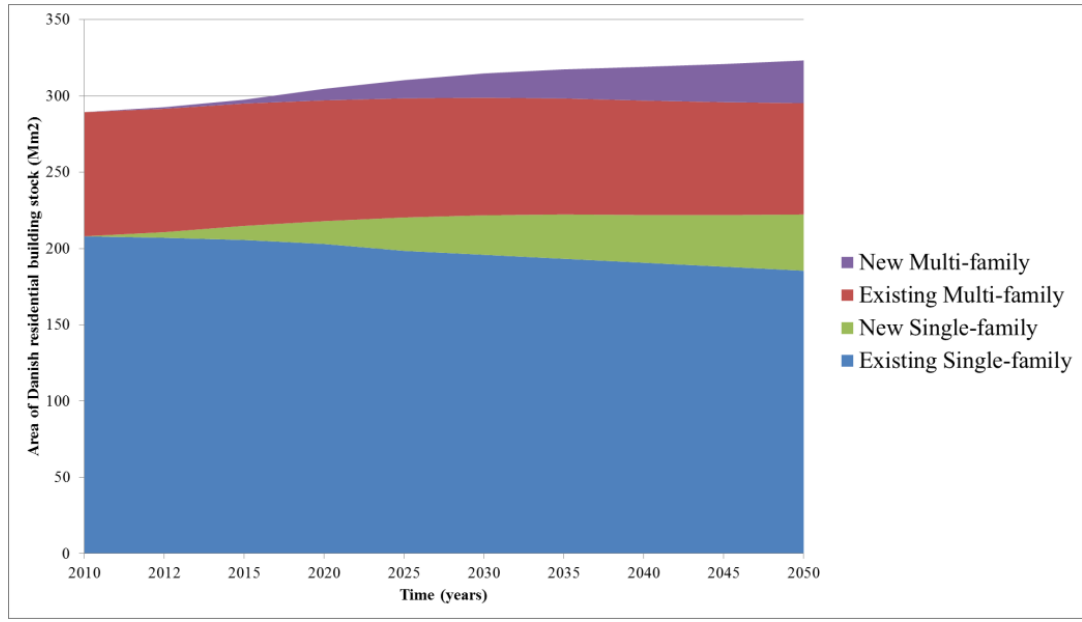


Figure 4. Assumed development of residential building stock

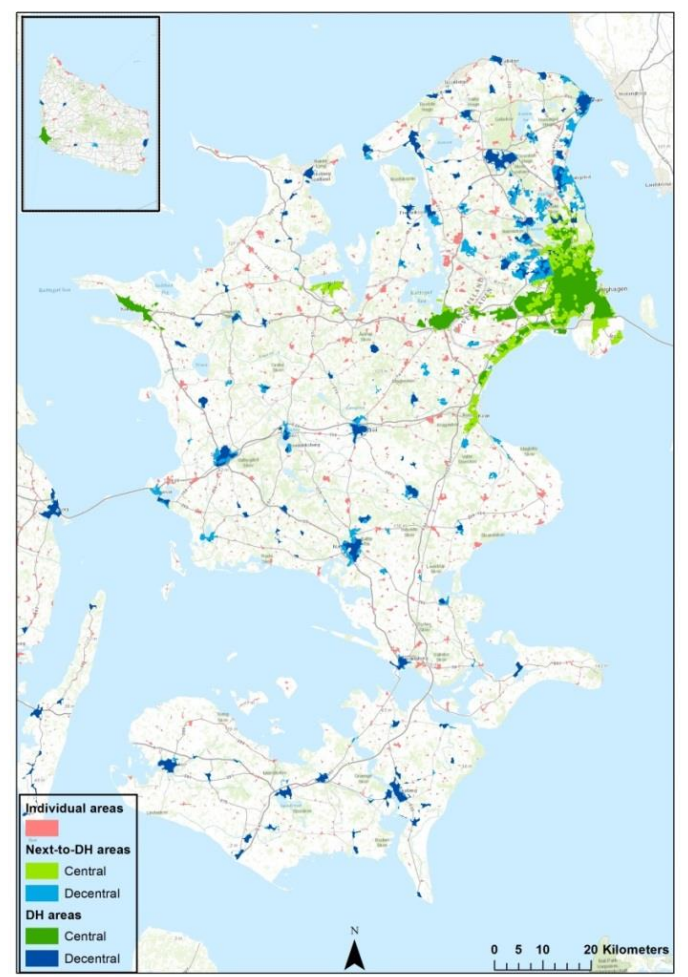

Figure 5. Central, Decentral and Individual areas in DKE

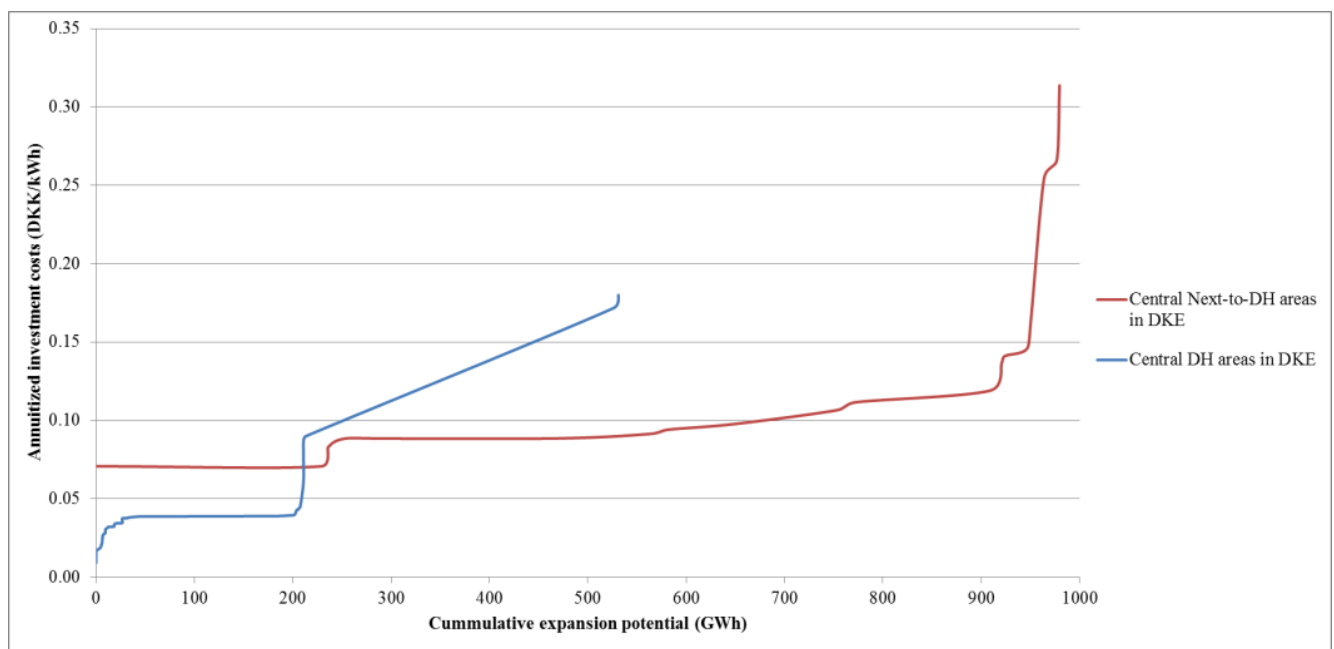

Figure 6. Cumulative potential for expansion of district heating and associated annuitized investment costs 


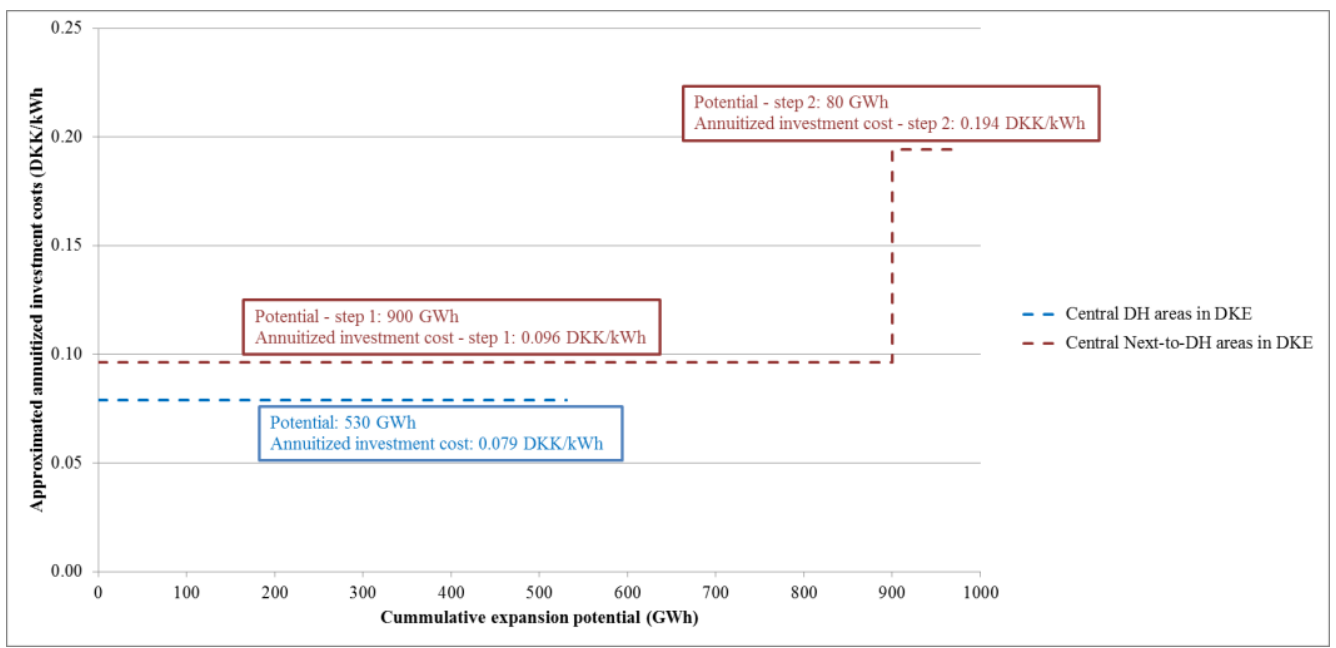

Figure 7. Approximated cumulative cost curves for district expansion

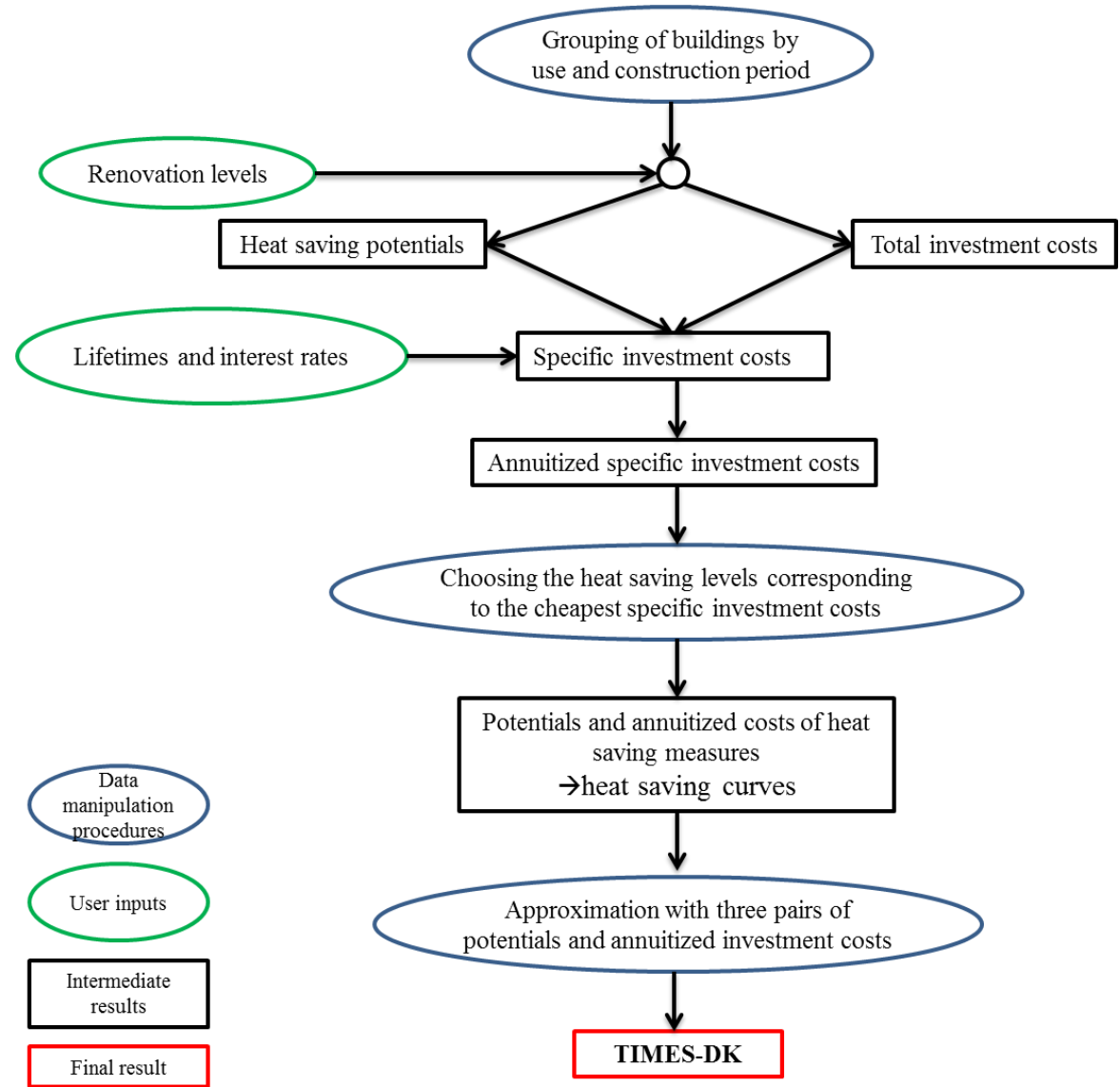

Figure 8. Feeding the potentials and costs of heat saving measures into TIMES-DK 


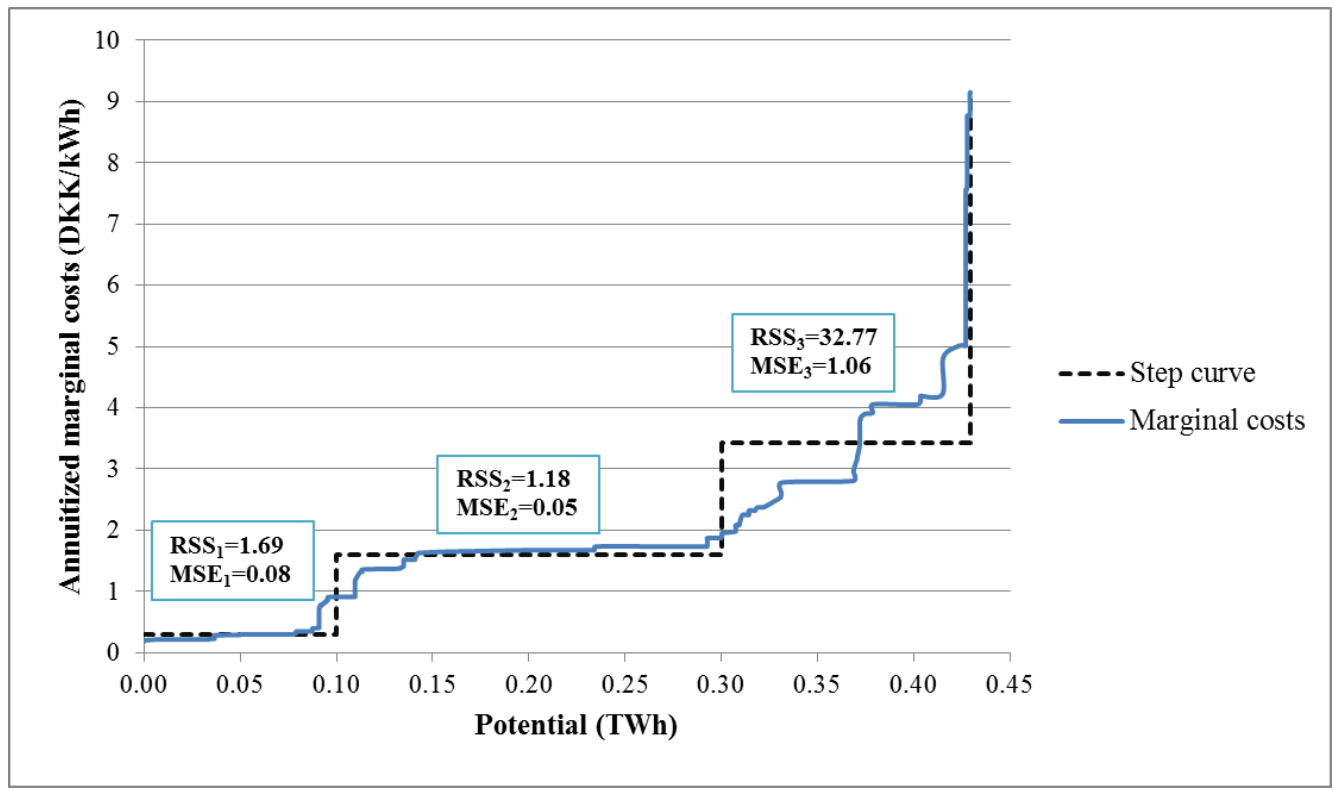

Figure 9. Heat saving potentials and associated annuitized investment costs and three-step approximation

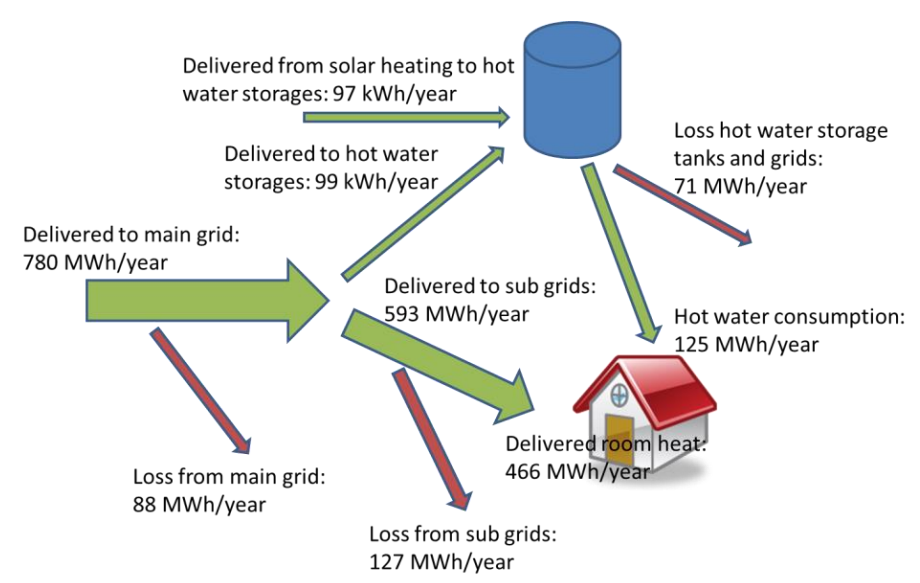

Figure 10. Heat flow in Munksøgård's heating system 


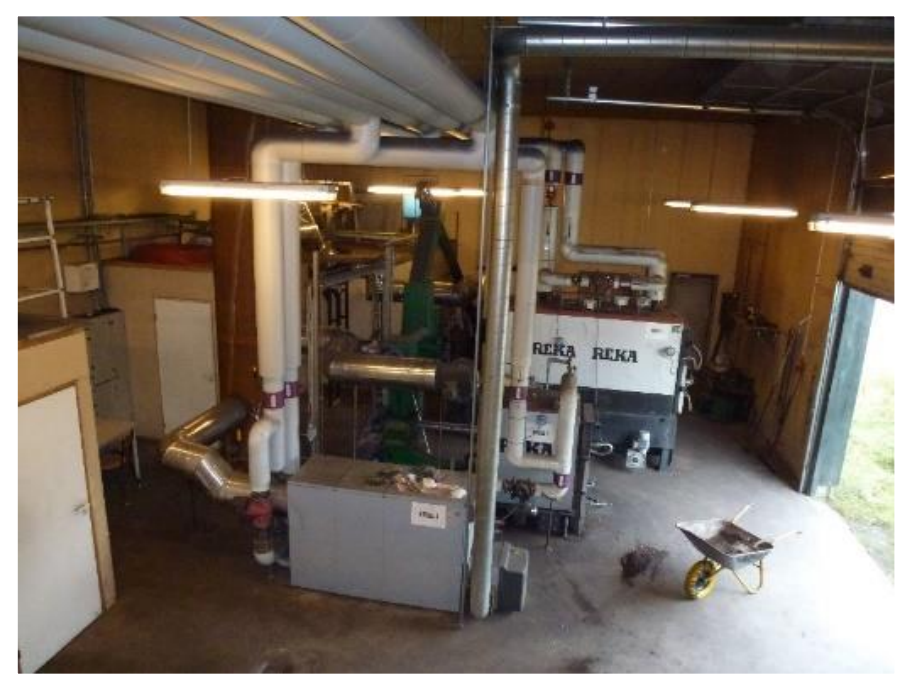

Figure 11. The three existing boilers $-250 \mathrm{~kW}$ oil boiler (in front), $60 \mathrm{~kW}$ wood pellet boiler (in the middle) and the $200 \mathrm{~kW}$ wood pellet boiler (in the back)

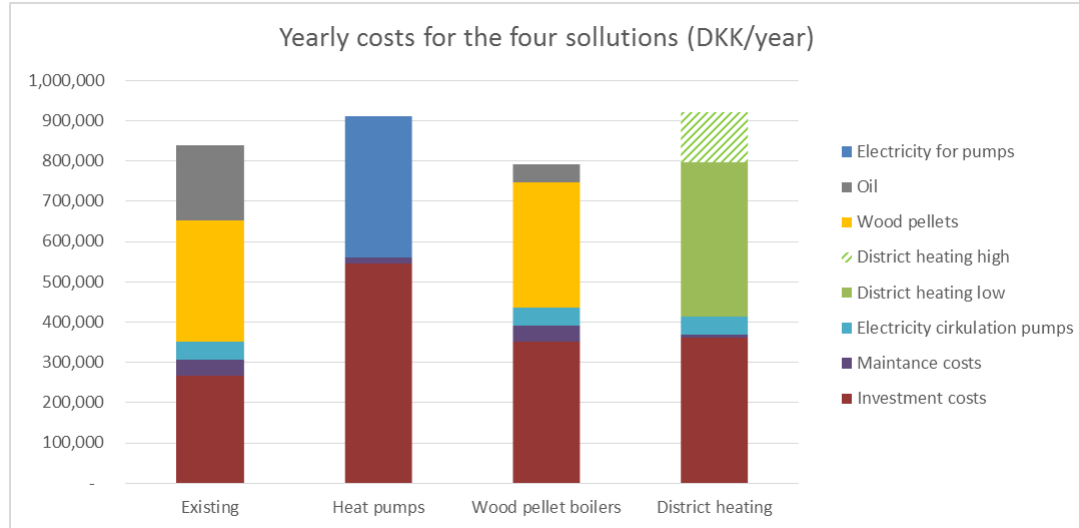

Figure 12. Annual costs for the four systems divided on costs types

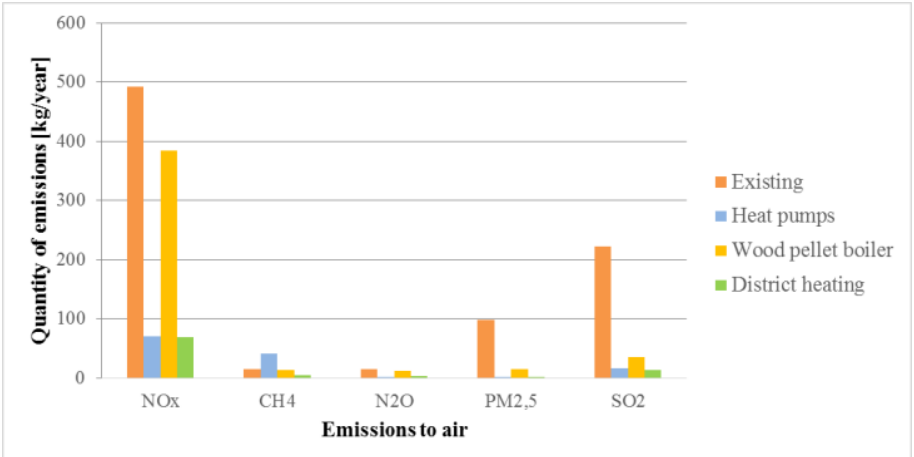

Figure 13. Air pollution from four solutions 


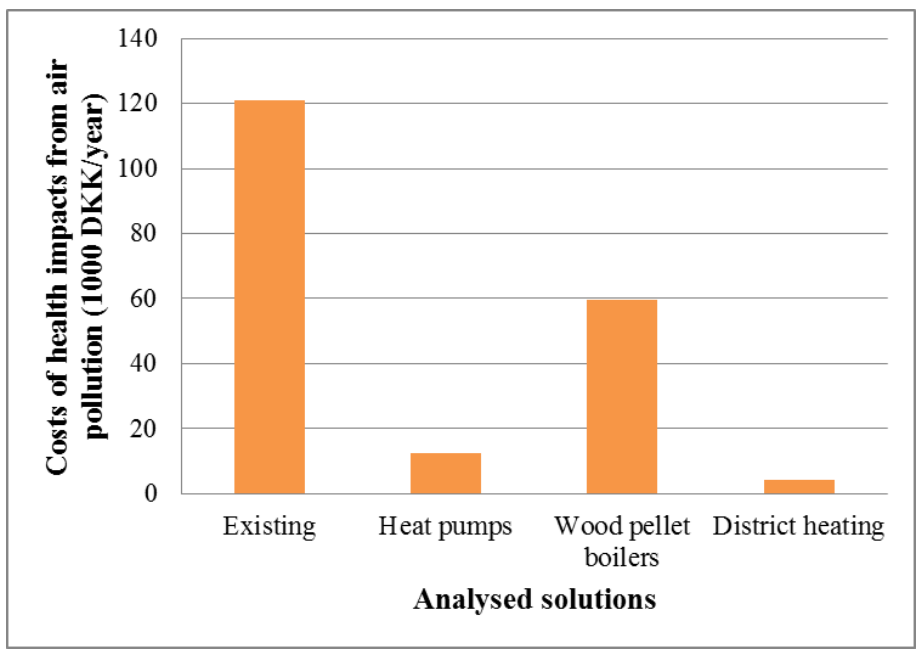

Figure 14. Socio-economic health costs from air pollution in each of the four cases

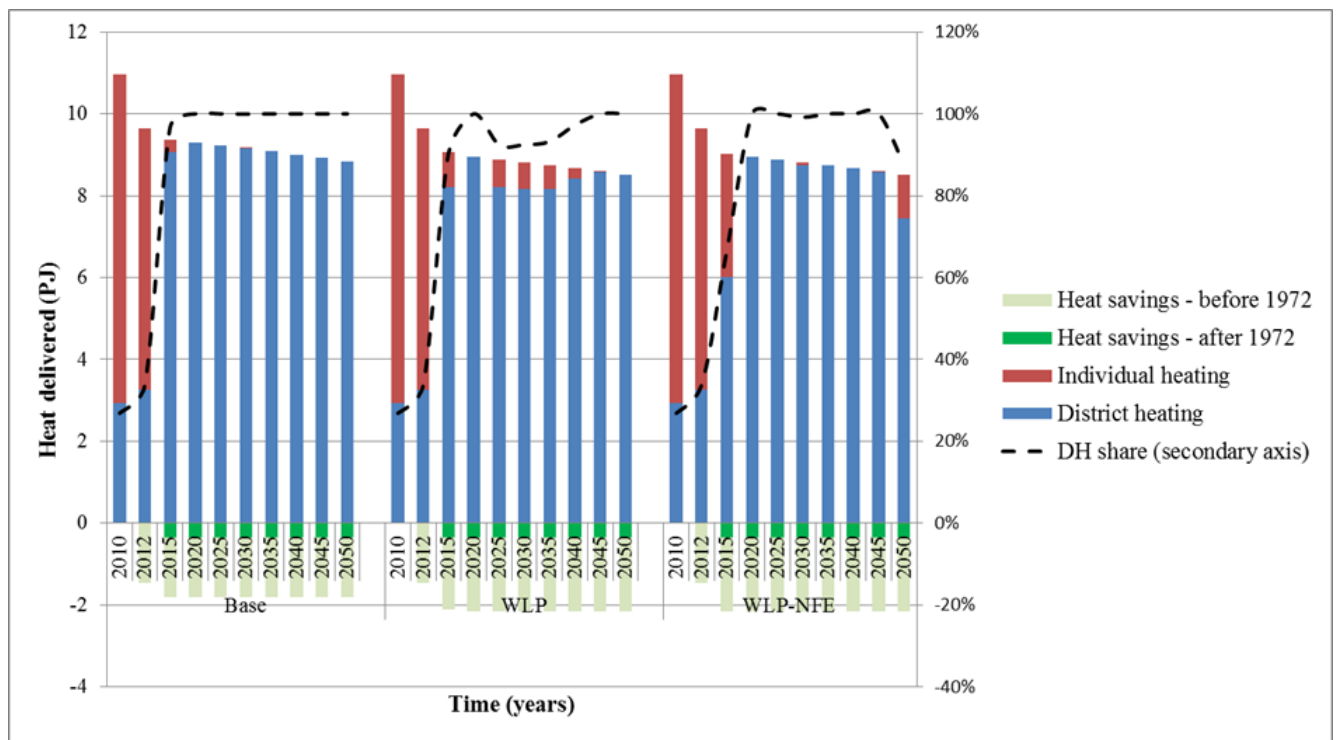

Figure 15. Heat supply to SF buildings located within Central areas in DKE 


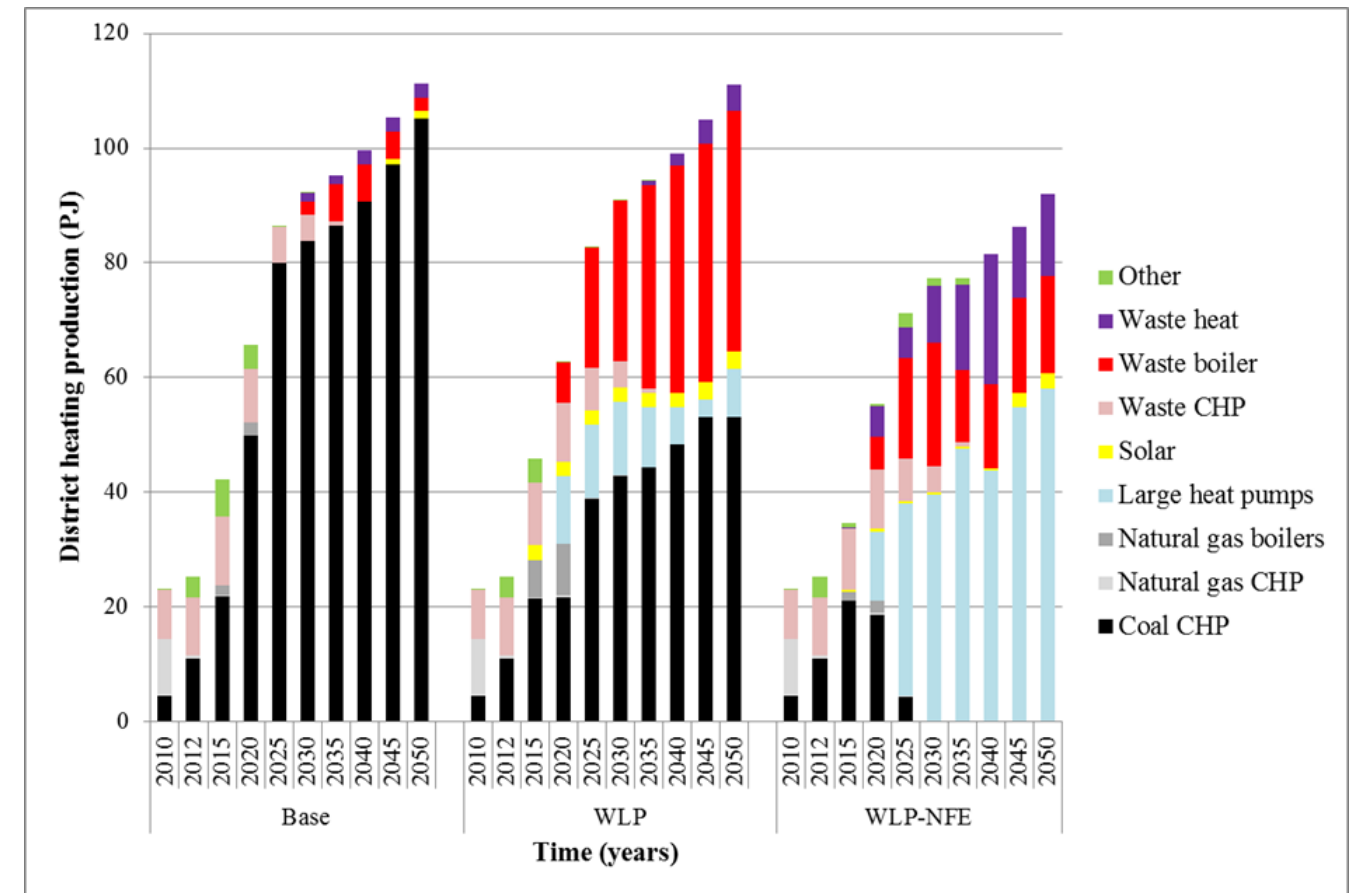

Figure 16. Production of district heating from Centralized plants located in DKE

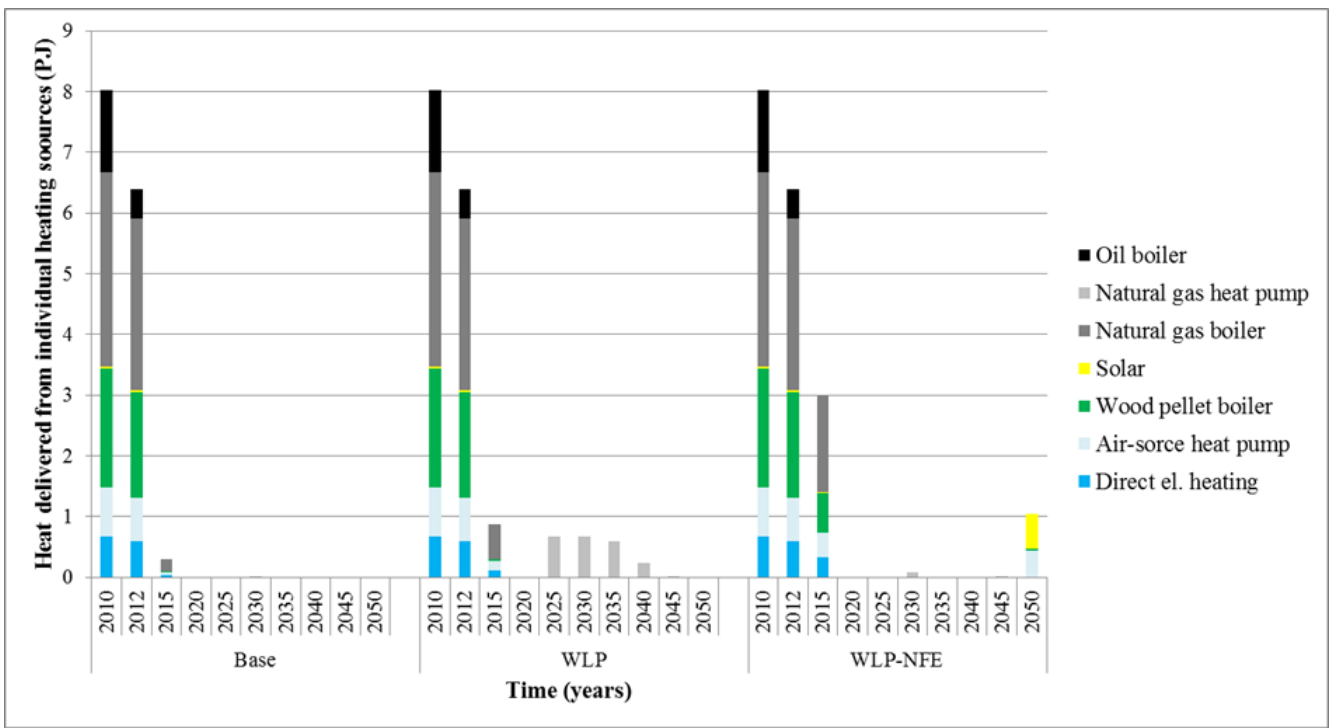

Figure 17. Heat delivered from individual heating sources to SF buildings located within Central areas in DKE 